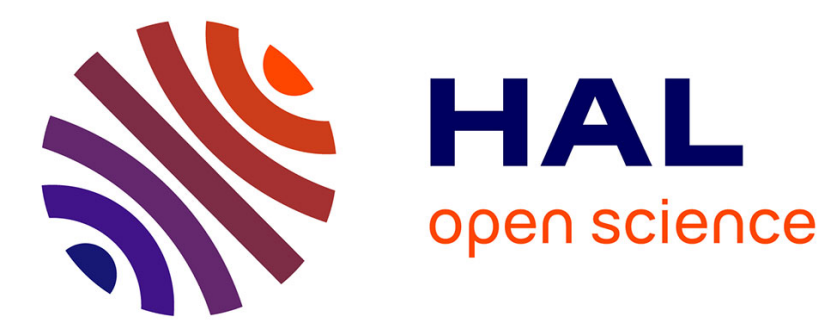

\title{
The use of insects in integrated weed management
}

\author{
Sandrine Petit, David Bohan
}

\section{To cite this version:}

Sandrine Petit, David Bohan. The use of insects in integrated weed management. Integrated weed management for sustainable agriculture, 42, Burleigh Dodds Science Publishing, 476 p., 2018, Burleigh Dodds Series in Agricultural Science, ISBN 13: 9781786761644. 10.19103/AS.2017.0025.23 . hal02789445

\section{HAL Id: hal-02789445 \\ https://hal.inrae.fr/hal-02789445}

Submitted on 5 Jun 2020

HAL is a multi-disciplinary open access archive for the deposit and dissemination of scientific research documents, whether they are published or not. The documents may come from teaching and research institutions in France or abroad, or from public or private research centers.
L'archive ouverte pluridisciplinaire HAL, est destinée au dépôt et à la diffusion de documents scientifiques de niveau recherche, publiés ou non, émanant des établissements d'enseignement et de recherche français ou étrangers, des laboratoires publics ou privés. 


\section{The Use of Insects in Integrated Weed Management}

Sandrine Petit and David A. Bohan, UMR Agroécologie, AgroSup Dijon, INRA, Université de Bourgogne Franche-Comté, France

1 Introduction

2 Deciphering complex interactions with generalist predator communities

3 Managing fields and landscapes to enhance weed seed predation

4 Extent of regulation

5 Case study: the UK national survey farm-scale evaluation

6 Conclusion

7 Future trends

8 Where to look for further information

9 References

\section{Introduction}

Many types of herbivorous insects feed on arable weeds, among which are leaf- and stem eaters, stem gallers, stem and root collar miners, capitula miners and seed feeders. The use of insects as biocontrol agents has mostly been investigated with a view of targeting exotic invasive weeds, and only to a limited extent has weed biocontrol been investigated in agricultural habitats. Numerous release programmes have been launched in Australia, New Zealand and North America over the last 100 years. Their success essentially hinges on agent establishment, effectiveness of control of the target weed and the risks to nontarget plants. However, there has been some success in controlling agricultural weeds, including control of tansy ragwort, Senecio jacobaea L., in New Zealand following the introduction of the flea beetle Longitarsus flavicornis (Suckling, 2013), the general consensus has been that these programmes have yielded highly variable results. In addition, reports of expansion of the range of plant hosts used by introduced biocontrol agents call into question the veracity of pre-release studies to evaluate the risks of an introduction for non-target organisms (Shaffner, 2001).

An alternative option to introducing alien biocontrol agents is to rely on insects that occur naturally at high abundance in arable agricultural fields, in what has been termed conservation biological control. Here the goal is to conserve and/or enhance populations of biocontrol agents, through appropriate management, to promote the control of pests. Conservation biological control is often not targeted directly at the pest, as the 
naturally occurring insects tend to be less selective in their prey. Rather, the conservation management supports communities of insects that could exert effects on weeds. The hypothesis, which is rather similar to the portfolio effect, is that amongst the community there will be at least one insect species capable of exerting control of weeds. To date, possibly the best documented case is the interaction between the community of seedeating carabid beetles and arable weeds. Seventy-four papers on this topic were identified from a literature review of the Web of Science (using 'weed seed predation' and 'carabid*' as search terms), with a steady increase since the first paper published in 1997; 27 papers were published between 2013 and 2016.

Carabid beetles are generalist predators that are very abundant in arable fields; many species contribute substantially to post-dispersal weed seed predation and could therefore represent valuable agents of weed control in agro-ecosystems (Honěk et al., 2003; Kulkarni et al., 2015). In contrast to herbicides, weed seed predators cannot robustly control standing weed numbers down to agreed sub-economic thresholds of damage to the crop. Rather, because seed predators affect weed seeds before they can germinate to become pestiferous, weed seed predation research aims to understand the relationship between carabid numbers and weed seed regulation, which can be defined as levels of predation that reduce the growth rate of the weed seedbank to below the replacement value (unity). The predation occurs in brief and intense periods of seed consumption (pulses) that follow recurrent weed seed rain episodes, and before seeds are protected by burial by the meteorological action of rain and wind (Westerman et al., 2009; Davis and Raghu, 2010). Carabid species exhibit preferences in the seeds they consume (Honěk et al., 2003; Petit et al., 2014), determined by the size of seeds and the body size of the predators. Larger carabids tend to consume larger weed seeds (Honěk et al., 2007). There is clear, but anecdotal, evidence of a role of other factors in mechanisms driving carabid preferences, such as the nature of resources stored in the seed, the thickness of the seed coat and the presence of carabid-predator and-competitor species.

The regulation of pests that results from the activity of naturally present predators is frequently cited as an important ecosystem service in arable agriculture (Losey and Vaughan, 2006). To date, however, few natural enemy functions have been demonstrated to elicit regulation or have been applied with robustness and generality in real agro-ecosystems. For weed regulation and control, three key issues need to be addressed to improve our ability to predict the intensity and resilience of weed seed predation and to foster wider adoption of conservation biocontrol management options in commercial fields. Specifically, we need to:

- Improve understanding of the complexity and variability in the structure of weed seed/seed predator trophic networks. Who eats whom?

- Determine the combination of in-field and landscape management options that promote weed seed predators and predation;

- Predict the effect of weed seed predation on the demography of weeds - how much control can be expected.

\section{Deciphering complex interactions with generalist predator communities}

The body of research currently available suggests that complex multi-trophic interactions influence the fate of weed seeds. The hypothesis that increasing seed-eating predator

(C) Burleigh Dodds Science Publishing Limited, 2017. All rights reserved. 
abundance may lead to enhanced weed suppression in many agricultural systems is widely accepted (Gallandt et al., 2005; Westerman et al., 2005). While in some instances seedeating carabid abundance has been positively related to seed predation level (Menalled et al., 2007) or change in the weed seedbank (Bohan et al., 2011), other studies have failed to demonstrate such links (Davis and Raghu, 2010; Gaines and Claudio Gratton, 2010; Mauchline et al., 2005; Saska et al., 2008). The lack of a clear numerical response of weed predation to seed-eating carabid abundance possibly reflects differences in the species present in the experiment, and insufficient consideration may have been given to the diversity of trophic and functional roles within this group. The relative importance of 'granivorous' species, over omnivorous and carnivorous carabids, for the delivery of weed seed predation has been well studied (Trichard et al., 2013), even though granivorous carabids may represent only a small proportion of carabid community and many granivores may also feed on animal prey (Haschek et al., 2012).

Beyond the abundance of seed-eating carabids, carabid diversity may also drive the amount of seeds consumed in arable fields (Gaines and Claudio Gratton, 2010; Trichard et al., 2013). Increased species richness leads to an increase in the diversity of carabid body sizes and therefore an increase in the range of seeds consumed (Honěk et al., 2007). Such carabid diversity effects are also consistent with reinforcement of preferential associations between some granivorous functional groups and key weed functional groups, as established at a national scale by Brooks et al. (2012). For granivorous carabids, there appears to be a positive effect of seed predator diversity whereby resource use differences among species could lead to increased prey suppression by diverse communities (Finke and Snyder, 2010).

Despite a growing understanding that the variation in the interactions between carabids and weeds is important for explaining weed regulation, our ability to predict the intensity and resilience of weed seed predation delivered by carabid communities is limited by additional factors that can modulate these interactions. First, it is likely that densitydependent feeding effects are at play (Cardina et al., 1996; Cromar et al., 1999). Carabid satiation during periods of peak weed seed rain could have a large effect on the potential of seed-eating carabids to control weeds at certain times (Davis and Raghu, 2010). Overall seed consumption may therefore be affected by the density (population) of weed seeds and carabids (Frank et al., 2011). Second, there is evidence of intra-guild predation in carabid communities (Currie et al., 1996). Omnivorous carabids feed on one another and there are likely to be additional indirect (non-trophic) effects. Carabids might alter their behaviour, in response to the risk of intra-guild predation, by lowering their level of activity or by leaving prime foraging locations, in order to reduce their individual risk (Prasad and Snyder, 2004; Guy et al., 2008). Finally, several studies suggest the existence of shifts in diet, in seed-eating carabids, which depend upon the prevailing conditions (Marino et al., 2005; Mauchline et al., 2005; Brooks et al., 2012); indeed field surveys indicate that specific spatial associations vary in time (Trichard et al., 2014). Such prey switching has been found for carabids that can, for example, feed on weed seeds and animal pests such as slugs (Fig. 1). Perhaps more surprisingly, species that are often described as mostly 'granivorous' can feed nearly exclusively on animal prey depending upon the context. The nutritional status of Amara similata in oilseed rape fields, for example, has been shown to be positively related to the abundance of pollen beetle in the field (Haschek et al., 2012) and to decrease as insecticide use increases (Labruyere et al., 2016a). Alternative prey, and their availability, may therefore be key to the delivery of the weed seed predation service.

Recently, researchers have begun to examine, explicitly, the apparent complexity of interaction using trophic network approaches. Building food webs has proceeded using bibliographic approaches, to recover published data for the trophic interactions of carabids 


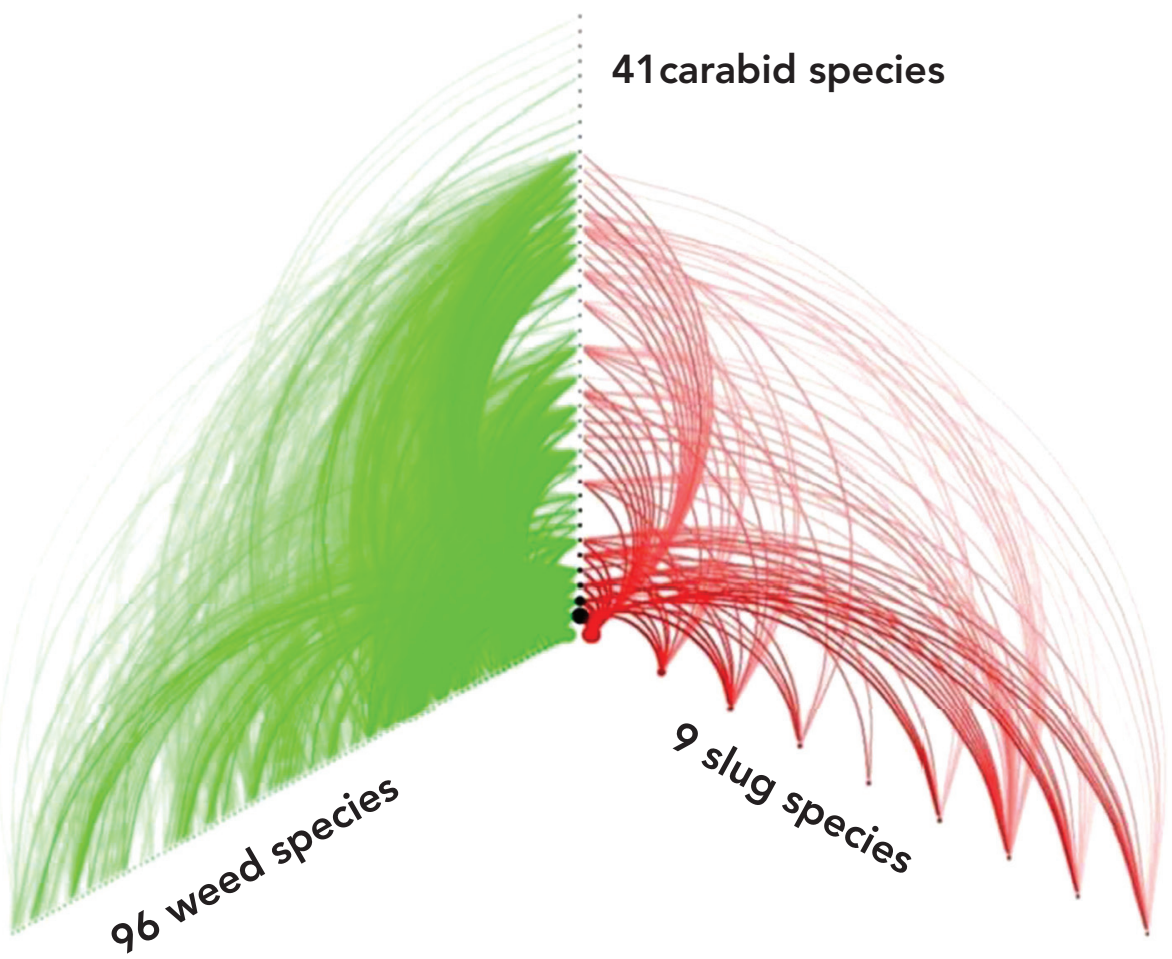

Figure 1 Hive plot of a composite food web constructed from the literature, aiding the data from the farm-scale evaluations (Section 3).

and their prey (e.g. Fig. 1). Food webs constructed this way are subject to the vagaries of the quality of the literature. In any food web, there are 'recovered' links that will prove to be false, reflecting either an apparent but incorrectly evaluated trophic link in the literature or an inappropriate attribution of a feeding link in the bibliographic approach itself. The approach also cannot recover unpublished or unobserved links and so these food webs are likely to be incomplete.

Scrutiny of food webs constructed in this manner, which integrate the entirety of the carabid literature, supports many of the findings made to date from individual studies and underscores the complexity of interaction between ecological regulation functions that are commonly treated separately. In a network of carabids, slugs and weeds from arable agriculture, it is clear that there are a great many putative interactions already present in the literature (Fig. 1). The carabid species do not all share the same patterns of linkage. Some species are relatively specialist, concentrating on a few prey species. The majority of carabids appear quite generalist, being linked to a great many prey species. Among these generalists, some species are granivores, being linked only to plants, although most generalists appear to use a mixture of plant and animal prey species. There is also some evidence that predation of weeds by carabids is partly determined by carabid predation of slugs; there are interactions between these two ecological functions. The links to the weeds appear to be contingent upon the number of links to the slugs, and as the number 
of trophic links to the slugs increases, the number of links to the weeds declines. This suggests that prey switching depends upon the prevailing context of alternative prey.

The aim of this food web-based approach to carabid-weed interactions is to identify coherent groups of carabid species that deliver predictable trophic functions and may be managed together. While this work has begun using bibliographic approaches, the goal is to expand this research to include molecular trophic methods that much more precisely and robustly determine feeding interactions, exclude false-positive links and greatly increase the completeness of description of the trophic links in agriculture. Molecular approaches to carabid predation of prey commenced during the 1990s with monoclonal antibodybased approaches. The monoclonal antibodies were raised to particular proteins of a prey species, such as certain slug proteins (Symondson et al., 1997; Bohan et al., 2000), and used to screen the gut contents of sampled carabids for the presence of those proteins. While a great advance, the monoclonal approach suffered from both being limited to a speciesby-species search for already-known prey and being destructive to the carabid predator. More recently, DNA-based approaches have begun to address these issues. Multiplex PCR primers allow many prey species to be screened simultaneously (King et al., 2011), and sampling carabid gut contents can now be done non-destructively using a method whereby individual carabids are provoked into regurgitating their stomach contents (Wallinger et al., 2015). The use of next-generation sequencing approaches, a catch-all name for a number of high-throughput sequencing approaches, also offers the potential for widening the assessment of prey species beyond those already known or suspected to affect plant species (Traugott et al., 2013). The reconstruction of ecological networks from DNA data is a growing topic of research (Vacher et al., 2016; Kamenova et al., 2017; Bohan et al., in press).

\section{Managing fields and landscapes to enhance weed seed predation}

A number of recent studies have attempted to identify in-field and landscape management options that might support predation of weed seeds. Managements that have been shown to substantially affect carabid richness, abundance or activity include in-field options and the compositional and structural aspects of the landscape surrounding fields, given that carabids are mobile organisms that respond at spatial scales much larger than the field (Kromp, 1999; Kulkarni et al., 2015).

Field management options can markedly affect weed seed fate. In general, weed seed predation has been found to be higher where in-field crop management intensity is lower, such as in no-till fields (Cromar, 1999; Menalled et al., 2007) and in fields with significant vegetation cover (Gallandt et al., 2005; Meiss et al., 2010; Sanguankeo and Leon, 2011). However, several studies have failed to detect any effect of in-field management on carabid abundance or weed seed predation, such as in organic farming (Diekötter et al., 2010; Jonason et al., 2013). In other situations, such as conservation agriculture, increased carabid abundance did not translate into enhanced weed seed predation, possibly because of a concomitant increase in the availability of alternative prey in these systems (Trichard et al., 2014).

At landscape scales, the amount of particular habitats and the complexity in spatial arrangement of those habitats could have important effects on weed seed predation. 
The proportion of organic farming at the landscape scale was shown to enhance the activity and increase the body size of granivorous carabid species, thus improving their potential to control arable weeds (Diekötter et al., 2016). The effect of landscape properties on weed seed predation per se is, however, poorly documented to date, with often equivocal, probably context-dependent results (Menalled et al., 2000; Trichard et al., 2013; Jonason et al., 2013). Moreover, in-field management effects appear conditional on the landscape and vice versa. For example, seed predation in organic fields is enhanced in complex landscapes, whereas predation in conventional fields is enhanced only in simple, relatively homogeneous farm landscapes (Fisher et al., 2011). A recent large-scale study also demonstrated that weed seed predation co-varied with both landscape composition and in-field management, that is, the duration since conversion to conservation agriculture (Petit et al., 2017). Levels of weed seed predation in fields that were managed in conservation agriculture for less than four years were dependent on the properties of the surrounding landscape. Conversely, fields in conservation agriculture for four years, or more, tended to have higher weed seed predation with only a very limited effect due to the landscape context (Petit et al., 2017).

From an applied perspective, conservation management options that would promote weed seed predation remain unclear. In addition, management strategies aiming at supporting carabids across a farmland landscape will likely also benefit other organisms (Gonthier et al., 2014). Given that most seed-eating carabids are generalist predators (Sunderland, 2002; Tooley and Brust, 2002), any increase in the range of alternative prey available for carabids due to landscape management will permit prey switching and thus threaten the resilient delivery of weed seed regulation services.

This complexity of interaction between the biotic and abiotic elements of the agroecosystem makes the controlled study of carabid weed seed predation and weed regulation both difficult and imperative. In addition to the classical field manipulation experiments that have been done to date, we imagine the future use of long-term monitoring approaches and more finely controlled mesocosm experiments as a possible solution to elucidating the mechanisms that determine weed seed predation. Long-term monitoring might use a standard suite of methods to sample carabid abundance and estimate seed predation. Critically, this would be done in replicated landscapes across a gradient of landscape and management diversities that reflect the current farming situation. In France, the national monitoring network SEBIOPAG might provide a model for this kind of work (http://sebiopag.inra.fr). Mesocosms, which are mid-scale experimental systems that are used to evaluate the field environment under controlled conditions (e.g. Stewart et al., 2013), could be used to much more finely manipulate biotic conditions to estimate their effect on weed seed predation. In particular, both the diversity of cover crop plants, which are increasingly used in European agriculture, and alternative prey abundance and diversity could be precisely manipulated to understand their interaction, the lack of which currently renders the prediction of conservation management for seed predation so difficult.

\section{Extent of regulation}

The episodic nature of weed seed predation over the course of a year makes the estimation of annual seed loss due to seed predation in the field highly variable and subject to error

(c) Burleigh Dodds Science Publishing Limited, 2017. All rights reserved. 
without careful repeated measurement (Westerman et al., 2003). From ten published datasets, Davis et al. (2011) estimated that annual seed losses due to invertebrates averaged $40 \%$ and ranged from $8 \%$ to $70 \%$ depending on the weed species and the agronomic context. Subsequent studies on weed seed predation by invertebrates have yielded estimates within this range. The annual rate of seed depletion by invertebrate predators can therefore be substantial, but there has been little documentation of the effect of seed predation on weed regulation and control. Evidence that rates of predation reported in the literature can affect the demography of particular weed species is still scarce, and few modelling studies have addressed this question. Results suggest that an annual seed loss of 25-50\% may be enough to slow down weed population growth substantially (Firbank and Watkinson, 1985; Westerman et al., 2005). Empirical evidence of effective regulation of the weed seedbank by carabid beetles is even scarcer; one of the few examples is the case study in Section 5. This lack of empirical evidence is the key information gap that remains to be filled. Demonstrating that ecological processes could be employed to replace herbicides and quantifying how much can be expected from these ecological processes represents the primary obstacle to the wider use of weed seed predation in agriculture.

\section{Case study: the UK national survey farm-scale evaluation}

One major limitation for a wider adoption of conservation biological control in arable agriculture is the lack of evidence and of quantification of the regulatory effect that can be expected. Establishing that carabids can elicit regulatory effects on the weed seedbank over a number of years and from fields undergoing the full range of management used in real-world farming would represent a major leap forward. Here, we present a demonstration case study, built on data collected during the Farm-Scale Evaluation (FSE) - a UK nationalscale field experiment done between 2000 and 2004.

\subsection{The FSE data}

The data on the abundance of the weed seedbanks, seed rain and carabids were collected from 66 spring-sown beet (both sugar and fodder), 59 spring maize, 67 spring oilseed rape and 65 winter oilseed rape fields (Bohan et al. 2005; Champion et al., 2003; Fig. 2). The fields were spread across the regions of the United Kingdom and sampled for one cropping year (Firbank et al., 2003) between 2000 and 2004. The pitfall trapping of carabids was conducted in the spring, summer and the late summer for the spring-sown crops and in the autumn, spring and summer for winter oilseed rape (Brooks et al., 2003; Bohan et al., 2005). Abundance of each carabid species, total carabids and the carabid functional groups of granivore and omnivore was available for each field. A total of 374638 individuals of 126 species were identified. Seedbank samples were taken just prior to sowing in two consecutive years (Heard et al., 2003). The seedbank counts were pooled to give an estimate of the seedbank in each field (total weeds). A total of 38402 seeds were sampled in the initial seedbank and 52662 seeds were sampled in the follow-up seedbank, representing some 201 taxa. The return of weed seed to the seedbank (seed rain) was also measured using seed rain traps (Heard et al., 2003). In total, 508777 seeds were shed into seed rain traps, and 211 taxa were identified. 

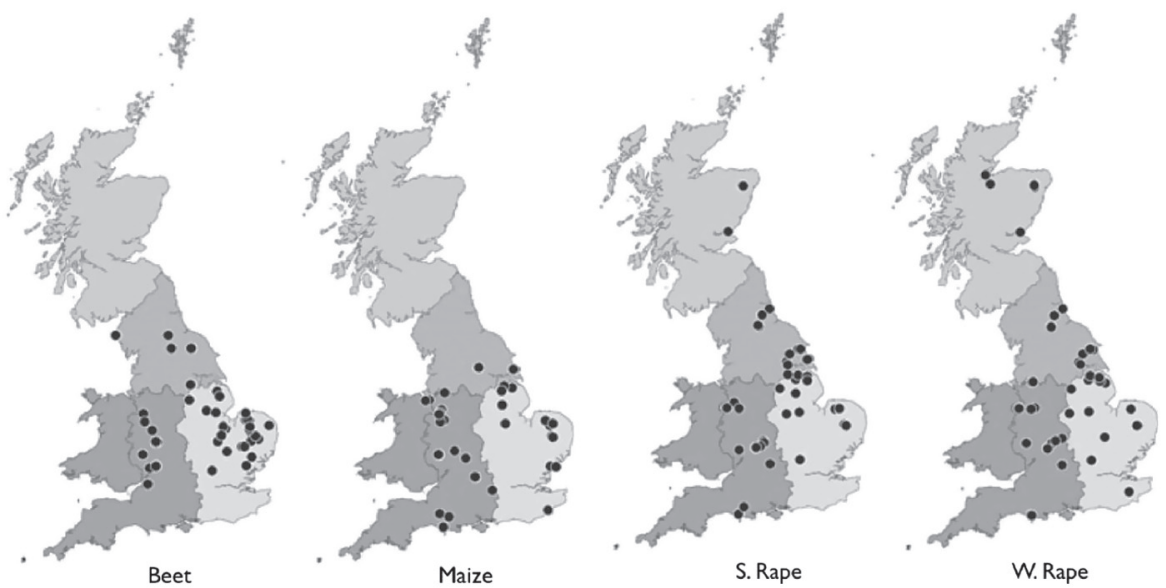

Figure 2 Distribution of the 66 spring-sown beet, 59 spring maize, 67 spring oilseed rape and 65 winter oilseed rape fields sampled as part of the FSE.

\subsection{Detecting signals of weed regulation in arable crops}

The analysis tested for the existence of a negative relationship between the change in the weed seedbank over a year and the abundance of carabids in that particular year, all other factors being equal (Bohan et al., 2011). Here, the seedbank is expected to change as weed seeds are shed (as seed rain from seeding plants) and return to the soil. If some of this seed rain is intercepted at the soil surface and eaten by seed predator carabids, it will reduce the amount returned to the seedbank. Where the interception rate is high and enough seeds are eaten, there will be a net decline in the seedbank over the year.

Analysis of the FSE dataset revealed a significant negative coefficient between the abundance of omnivores and the change in the monocotyledon weed seedbank from one year to the next, across all crops (Fig. 3a). A similar relationship could be established between the abundance of granivorous carabids and the change in the monocotyledon weed seedbank change, across all crops (Fig. 3b). That seedbank change was also found to be positively related to seed rain abundance and the abundance of carabids was positively related to total seed rain abundance. This suggests that the predation model of carabid weed seed regulation that was tested for, namely that carabid-intercepted seed rain caused a change in the seedbank, was consistent with the data. The carabid beetles appeared to regulate the weed seedbank.

\subsection{Identifying multiple-scale drivers of seed-eating carabid abundance in arable crops}

The relative contribution of in-field and landscape-scale management factors on the abundance of nine individual seed-eating carabid species was then assessed on a subset of 161 fields from the FSE dataset (Labruyere et al., 2016b). In-field management was described with a composite indicator accounting for crop yield, quantity of inputs, field size and the presence of beetle banks or conservation headlands. The effect of land use outside the focal field focused on two specific land use types that were hypothesized 

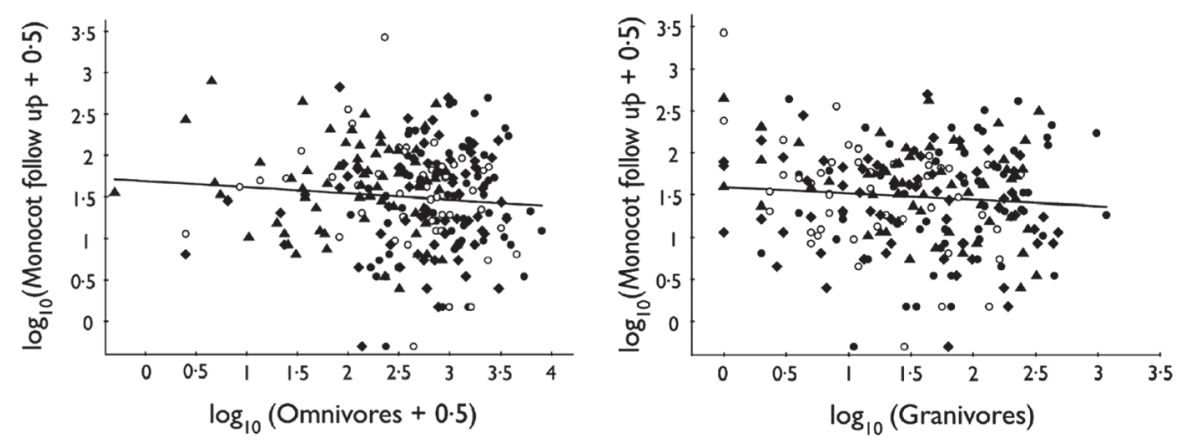

Figure 3 Multiple linear regression model fits between (a) the monocotyledon weed seedbank change and the abundance of omnivorous, and (b) the monocotyledon weed seedbank change and the abundance of granivorous (right plot) carabids in spring-sown beet (•), spring maize (0), spring oilseed

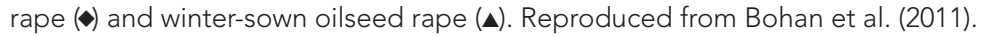

to provide seed resources: oilseed rape crops and grassland. For each field, the study quantified (i) the presence of oilseed rape or grassland adjacent to the crop (neighbouring effect) and (ii) the proportion cover of these land use types in a $5 \mathrm{~km}^{2}$ grid centred on the focal field (wider landscape effects).

The analysis revealed that the in-field carabid abundance responds to the spatial distribution of agricultural land use at three spatial scales. Locally, crop type strongly affected the abundance of individual species, in a species-specific manner, and the intensity of field management had a negative effect on the abundance of several species, irrespective of their trophic guild. In the neighbourhood, the occurrence of oilseed rape and grasslands was found to decrease the abundance of generalist seed-eating carabids, but it was the main factor positively affecting the abundance of the mainly granivorous Amara aenea, which occurred almost exclusively in our sampled oilseed rape fields. At the landscape scale, a generally positive effect of the cover of grassland and oilseed rape on in-field carabid abundance was detected, a finding which suggests that these habitats may provide alternative trophic resources to carabids, either seeds for granivorous carabids or alternative prey items for polyphagous species. These findings suggest that conservation management options would best be implemented at multiple spatial scales if used to promote weed seed predation in arable fields.

\section{Conclusion}

There is a critical need to assure future food security. Increasing emphasis will be placed on greater crop productivity while reducing environmental effects and reliance on chemical use in modern agriculture. Herbicides remain the predominant means of weed control, for instance, herbicides accounted for $42.3 \%$ of all pesticides used in Europe in 2010 (FAO). Policy-driven changes in herbicide use may lead to increases in weed plant densities in arable fields and reductions in crop productivity (Kim et al., 2002) and, more generally, the economic performance of agriculture. The move away from chemical weed control will thus only be possible if either there is an acceptance of a decline in yield or ecological functions and ecosystem services are available, which can be managed and function well enough 
to substitute for chemical inputs. For farmers to adopt these alternatives to herbicides, it will be necessary to show that ecological functions and services can replace herbicides with little or no additional risk to crop yield, farm productivity or profit. There is, however, a gap between the perceived need and the empirical evidence. This is mostly because regulation effects are neither robust/resilient nor is their management predictable under field conditions. Ecosystem services and conservation management currently represent a risk that is readily avoided by the continued use of herbicides.

Research can contribute to the overall goal of reducing reliance on herbicide use in several ways. The primary aim should be to produce a functional understanding of the conservation managements necessary to deliver the ecosystem service of carabid weed seed predation in place of herbicides. It is expected that local and landscape-scale management of arable fields could be used to increase the abundance of carabids, but that concomitant modification of the abundance and diversity of alternative prey may interfere with the delivery of high and resilient weed biocontrol. Quantifying and understanding the underlying mechanisms that link conservation managements to the delivery of the weed seed predation service will require the use of a combination of approaches that encompass large-scale surveys, mesocosms and manipulative experiments in which trophic feeding links between carabids, weed and alternative prey species are precisely determined by molecular analysis of carabid regurgitates (Wallinger et al., 2015). Such studies would test whether a high biodiversity of weed seed predators will assure natural weed regulation in agriculture and should elucidate the trophic consequences of contrasted agricultural management options. It will also generate the knowledge necessary to guide farming management strategies and will have a direct effect on all stakeholders, policy makers, farmers and the public by demonstrating a general, robust delivery of ecosystem services that are i) cost-effective, ii) credible for farmers to adopt and iii) able to maintain productivity services in the face of policy changes to pesticide inputs (e.g. Ecophyto 2018).

\section{Future trends}

Currently, we do not know whether, or how effectively, carabids can regulate the weed seedbank. Evidence such as the national-scale study by Bohan et al. (2011) would suggest that carabids can intercept weed seed rain and thereby cause changes in the weed seedbank that are consistent with regulation. However, the stomach contents of the carabids were never investigated for weed seed remains and, consequently, it is possible that this pattern was merely an artefact. It is also true that measuring weed seedbank change in the field is extremely difficult and costly. This means that sampling the weed seedbank is rarely done and most studies use seed predation estimates from seed predation cards, to estimate the effect of carabids. There are clear gaps in our current understanding and estimation of seed predation and regulation. In the future, it will be necessary to demonstrate clearly, using molecular approaches, that carabid feeding changes the weed seedbank and that seed predation cards are valid proxies for weed seedbank regulation.

Weeds and carabids exist within a wider ecological network of agricultural species (Pocock et al., 2012). This network is actually a meta-network of a wide variety of ecological interactions. It includes direct interactions, such as competition and trophic interactions studied by ecologists. It also includes other rather less well-studied indirect interactions, such as the provision of shelter. Weeds play a key role in this meta-network providing 
both food and shelter resources to a wide variety of animal species, including carabids. For the future, an important line of research will be to fully describe this network and place all species in their appropriate context. The importance of this is that these links (interactions) lie at the core of ecological functions. Trophic and competition interactions between the species of the network become the regulatory functions and ecosystem services we wish to harness in biological control. Understanding how the diversity and structure of these agricultural meta-networks vary with local and landscape management, particularly directed at weeds, will lead to better prediction of the resilience of regulation and the management that can better support biocontrol.

From a study of one of the most complete agricultural meta-network yet produced, Pocock et al. (2012) demonstrated that the different ecological functions varied in their robustness, with pollinators being particularly fragile to loss of weed species, but there was no strong co-variation in function because the different interaction types were often in conflict. This network-based approach revealed there was no 'optimist's scenario' or 'winwin' management that benefited both biodiversity and multiple ecosystem functions. In essence, this suggests that only a subset of ecological functions can be managed, which places a great emphasis on identifying those interactions that are in conflict. As already discussed in Section 2.1, carabid predation of weed seeds and carabid predation of slugs may be antagonistic and, by extension, all alternative prey could have such interference effects. There is a need, therefore, to evaluate the interactions and antagonisms between ecological interactions across a framework of a meta-network, and it appears to us that the developing technology of next-generation sequencing offers great promise for the identification of both direct and indirect interactions (Vacher et al., 2016; Kamenova et al., 2013; Bohan et al., 2017).

\section{Where to look for further information}

A great introduction to weed seed predation by carabids is given in the review by Kulkarni et al. (2015), which covers many of the critical issues. Readers will find the paper an easyto-read introduction to the subject and a great source of further reading. A more general introduction to seed predation and plant population dynamics can be found in Crawley (2000).

Beyond the large ecological organizations, such as the BES and ESA, discussion of weed seed predation by insects can be found across a variety of international societies and their meetings. Primary amongst these are the European Weed Research Society Weeds and biodiversity working group (http://www.ewrs.org) and a number of working groups of the International Organisation for Biological Control (IOBC - http://www.iobcglobal.org). Specific sessions on weed seed predation by carabids can be found at the meetings of the European Carabidologists (e.g. https://colloque.inra.fr/18ecm/The-18thEuropeanCarbidologist-Meeting/18th-ECM-2017), which have occurred approximately every two years since 1969. More recent developments include international meetings on molecular approaches and ecological networks including the joint Symposium on the Molecular Analysis of Trophic Interactions and Symposium on Ecological Networks (e.g. http://www.slu.se/ecology-symposium), which also occur every second year.

There are a considerable number of research groups active or previously active in research into carabid predation, including carabid predation of weed seeds. A rapid tour 
of the World Wide Web using Google will highlight many of these groups, including those from the United States. Here, as a guide for such a tour of the web, we list five groups that are currently active and doing important research. The newly formed group of Klaus Birkhofer, at Brandenburgische Technische Universität (BTU) Cottbus - Senftenberg in Germany, works on understanding how farm management affects predation and predationderived services in agriculture. At Wageningen, the Netherlands, Wopke van der Werf and colleagues study the statistical ecology of regulation services, and in particular weed regulation. Paula Westerman, at the University of Rostock, seeks to understand seed predation ecology using a variety of invertebrate and vertebrate weed seed predators, including carabids. Pavel Saska and colleagues, at the Czech Crop Research Institute, use classical and molecular ecological approaches to understand weed seed predation. At the University of Innsbruck, Austria, the world-renowned team of Michael Traugott develop molecular approaches to understand the trophic ecology of predation, including carabid trophic interactions with weeds.

\section{References}

Bohan, D. A., Bohan, A., Glen, D. M., Symondson, W. O. C. and Wiltshire, C. (2000). Spatial dynamics of predation by carabid beetles on slugs. Journal of Animal Ecology. 69, 367-79.

Bohan, D. A., Boffey, C. W. H., Brooks, D. R., Clark, S. J., Dewar, A. M., Firbank, L. G., Haughton, A. J., Hawes, C., Heard, M. S., May, M. J., Osborne, J. L., Perry, J. N., Rothery, P., Roy, D. B., Scott, R. J., Squire, G. R., Woiwod, I. P. and Champion, G. T. (2005). Effects on weed and invertebrate abundance and diversity of herbicide management in genetically modified herbicide-tolerant winter-sown oilseed rape. Proceedings of the Royal Society of London Series B, Biological Sciences, 272, 463-74.

Bohan, D. A., Boursault, A., Brooks, D. R., Petit, S. (2011). National-scale regulation of the weed seedbank by carabid predators. Journal of Applied Ecology, 48, 888-98.

Bohan, D. A., Vacher, C., Tamaddoni-Nezhad, A., Raybould, A., Dumbrell, A. J. and Woodward, G. (2017). Next-generation Global Biomonitoring - large-scale, automated reconstruction of ecological networks. Trends in Ecology and Evolution, 32, 477-87.

Brooks, D. R., Bohan, D. A., Champion, G. T., Haughton, A. J., Hawes, C., Heard, M. S., Clark, S. J., Dewar, A. M., Firbank, L. G., Perry, J. N., Rothery, P., Scott, R. J., Woiwod, I. P., Birchall, C., Skellern, M. P., Walker, J. H., Baker, P., Bell, D., Browne, E. L., Dewar, A. J. G., Fairfax, C. M., Garner, B. H., Haylock, L. A., Horn, S. L., Hulmes, S. E., Mason, N. S., Norton, L. R., Nuttall, P., Randle, Z., Rossall, M. J., Sands, R. J. N., Singer, E. J. and Walker, M. J. (2003). Invertebrate responses to the management of genetically modified herbicide-tolerant and conventional crops. I. Soil-surface-active invertebrates. Proceedings of the Royal Society of London Series B-Biological Sciences, 358, 1847-62.

Brooks, D. R., Storkey, J., Clark, S. J., Firbank, L. G., Petit, S. and Woiwod, I. P. (2012). Trophic links between functional groups of arable plants and beetles are stable at a national scale. Journal of Animal Ecology, 81, 4-13.

Cardina, J., Norquay, H. M.; Stinner, B. R. and McCartney, D. A. (1996). Postdispersal predation of velvetleaf (Abutilon theophrasti) seeds. Weed Science, 44, 534-9.

Champion, G. T., May, M. J., Bennett, S., Brooks, D. R., Clark, S. J., Daniels, R. E., Firbank, L. G., Haughton, A. J., Hawes, C., Heard, M. S., Perry, J. N., Randle, Z., Rossall, M. J., Rothery, P., Skellern, M. P., Scott, R. J., Squire, G. R. and Thomas, M. R. (2003). Crop management and agronomic context of the Farm Scale Evaluations of genetically modified herbicide-tolerant crops. Philosophical Transactions of The Royal Society of London, Series B, 358, 1801-18.

Crawley, M. J. (2000). Seed predators and plant population dynamics. In M. Fenner (ed.), Seeds: The Ecology of Regeneration in Plant Communities. CABI, New York, USA, pp. 167-82. 
Cromar, H. E., Murphy, S. D. and Swanton, C. J. (1999). Influence of tillage and crop residue on post dispersal predation of weed seeds. Weed Science, 47, 184-94.

Currie, C. R., Spence, J. R. and Niemelä,J. (1996). Competition, cannibalism and intra guild predation among ground beetles (Coleoptera: Carabidae): a laboratory study. The Coleopterists Bulletin, $50,135-48$.

Davis, A. S. and Raghu, S. (2010). Weighing abiotic and biotic influences on weed seed predation. Weed Research, 50, 402-12.

Davis, A. S., Daedlow, D., Schutte, B. J. and Westerman, P. R. (2011). Temporal scaling of episodic point estimates of seed predation to long-term predation rates. Methods in Ecology and Evolution, 2, 682-890.

Diekötter, T., Wamser, S., Wolters, V. and Birkhofer, K. (2010). Landscape and management effects on structure and function of soil arthropod communities in winter wheat. Agriculture, Ecosystems and Environment, 137, 108-12.

Diekötter, T., Wamser, S., Dörner,T. Wolters, V. and Birkhofer, K (2016). Organic farming affects the potential of a granivorous carabid beetle to control arable weeds at local and landscape scales. Agricultural and Forest Entomology, 18, 167-73.

Finke, D. L. and Snyder, W. E (2010). Conserving the benefits of predator biodiversity. Biological conservation, 143, 2260-9.

Firbank L. G. and Watkinson A. R. (1985). On the analysis of competition within two-species mixtures of plants. Journal of Applied Ecology. 22, 503-17.

Firbank, L. G., Heard, M. S., Woiwod, I. P., Hawes, C., Haughton, A. J., Champion, G. T., Scott, R .J., Hill, M. O., Dewar, A. M., Squire, G. R., May, M. J., Brooks, D. R., Bohan, D. A., Daniels, R. E., Osborne, J. L., Roy, D. B., Black, H. I. J., Rothery, P, and Perry, J. N. (2003). An introduction to the Farm-Scale Evaluations of genetically modified herbicide-tolerant crops. Journal of Applied Ecology, 40, 2-16.

Fischer, C., Thies, C. and Tscharntke, T. (2011). Mixed effects of landscape complexity and farming practice on weed seed removal. Perspectives in Plant Ecology, Evolution and Systematics, 13, 297-303.

Frank, S. D., Shrewsbury P. M. and Denno, R. F. (2011). Plant versus prey resources: Influence on omnivore behaviour and herbivore suppression. Biological Control, 57, 229-35.

Gaines, H. R. and Claudio Gratton, C. (2010). Seed predation increases with ground beetle diversity in a Wisconsin (USA) potato agroecosystem. Agriculture, Ecosystems and Environment, 137, 329-36.

Gallandt, E. R., Molloy, T., Lynch, R. P. and Drummond, F. A. (2005). Effect of cover-cropping systems on invertebrate seed predation. Weed Science, 53, 69-76.

Gonthier, D., Ennis, K., Farinas, S., Hsieh, H.-Y., Iverson, A., Batáry, P., Rudolphi, J., Tscharntke, T., Cardinale, B. and Perfecto, I. (2014). Biodiversity conservation in agriculture requires a multiscale approach. Proceedings of the Royal Society B: Biological Sciences, 281 (1791).

Guy, A., Bohan, D. A., Powers, S. J. and Reynolds, A. M. (2008). Avoidance of conspecific odour by carabid beetles: a mechanism for the emergence of scale-free searching patterns. Animal Behaviour, 76, 585-91.

Haschek, C., Drapela, T., Schuller, N., Fiedler, K., Frank, T. (2012). Carabid beetle condition, reproduction and density in winter oilseed rape affected by field and landscape parameters. Journal Applied Entomology. 136, 665-74.

Heard, M. S., Hawes, C., Champion, G. T., Clark, S. J., Firbank, L. G., Haughton, A. J., Parish, A. M., Perry, J. N., Rothery, P., Scott, R. J., Skellern, M. P., Squire, G. R. and Hill, M. O. (2003). Weeds in fields with contrasting conventional and genetically modified herbicide-tolerant crops I. Effects on abundance and diversity. Philosophical Transactions of The Royal Society of London, Series $B, 358,1819-33$.

Honěk, A., Martinkova, Z. and Jarošík, V. (2003). Ground beetles (Carabidae) as seed predators. European Journal of Entomology. 100, 531-44.

Honěk, A., Martinkova, Z., Saska, P. and Pekar, S. (2007). Size and taxonomic constraints determine seed preferences of Carabidae (Coleoptera). Basic and Applied Ecology, 8, 343-53. 
Jonason, D., Smith, H. G., Bengtsson, J. and Birkhofer, K. (2013). Landscape simplification promotes weed seed predation by carabid beetles (Coleoptera: Carabidae). Landscape Ecology, 28, 487-94.

Kamenova, S., Bartley, T. J., Bohan, D., Boutain, J. R., Colautti, R. I., Domaizon, I., Fontaine, C., Lemainque, A., Le Viol, I., Mollot, G., Perga, M. E., Ravigné, V. and Massol, F. (2017). Invasions toolkit: current methods for tracking the spread and impact of invasive species. Advances in Ecological Research, 56, 85-182.

Kim, D. S., Brain, P., Marshall, E. J. P. and Caseley, J. C. (2002). Modelling herbicide dose and weed density effects on crop:weed competition. Weed Research, 42, 1-13.

King, R. A., Moreno-Ripoll, R., Agusti, N., Shayler, S. P., Bell, J. R., Bohan, D. A. and Symondson, W. O. C. (2011). Multiplex reactions for the molecular detection of predation on pest and nonpest invertebrates in agroecosystems. Molecular Ecology Resources, 11, 370-3.

Kromp, B. (1999). Carabid beetles in sustainable agriculture: a review on pest control efficacy, cultivation impacts and enhancement. Agriculture, Ecosystems and Environment. 74, 187-228.

Kulkarni, S. S., Dosdall, L. M. and Willenborg, C. J. (2015). The role of ground beetles (Coleoptera: Carabidae) in weed seed consumption: a review. Weed Science, 63, 355-76.

Labruyere S., Ricci B., Lubac A. and Petit S. (2016a). Crop type, crop management and grass margins affect the abundance and the nutritional state of seed eating carabid species in arable landscapes. Agriculture Ecosystems and Environment, 231, 183-92.

Labruyere, S., Bohan, D. A., Biju-Duval, L., Ricci, B. and Petit, S. (2016b). Local, neighbor and landscape effects on the abundance of weed seed-eating carabids in arable fields: a nationwide analysis. Basic and Applied Ecology. 17, 230-9.

Losey, J. E. and Vaughan, M. (2006). The economic value of ecological services provided by insects. BioScience, 56, 311-23.

Marino, P. C., Westerman, P. R., Pinkert, C. and van der Werf, W. (2005). Influence of seed density and aggregation on post-dispersal weed seed predation in cereal fields. Agriculture, Ecosystems and Environment, 106, 17-25.

Mauchline, A. L., Watson, S. J., Brown, V. K. and Froud-Williams, R. J. (2005). Post-dispersal seed predation of non-target weeds in arable crops. Weed Research, 45, 157-64.

Meiss, H., Le Lagadec, L., Munier-Jolain, N., Waldhardt, R. and Petit, S. (2010). Weed seed predation increases with vegetation cover in perennial forage crops. Agriculture, Ecosystems and Environment, 138, 10-16.

Menalled, F. D., Marino, P. C., Renner, K. A. and Landis, D. A. (2000). Post-dispersal weed seed predation in Michigan crop fields as a function of agricultural landscape structure. Agriculture, Ecosystems and Environment, 77, 193-202.

Menalled, F. D., Smith, R. G., Dauer, J. T. and Fox, T. B. (2007). Impact of agricultural management on carabid communities and weed seed predation. Agriculture, Ecosystems and Environment, $118,49-54$.

Petit, S., Boursault, A. and Bohan, D. A. (2014). Weed seed choice by carabid beetles (Coleoptera: Carabidae): Linking field measurements with laboratory diet assessments. European Journal of Entomology, 111, 1-6.

Petit, S., Trichard, A., Biju-Duval L., McLaughlin, Ó. B. and Bohan, D. A. (2017). Interactions between conservation agricultural practice and landscape composition promote weed seed predation by invertebrates. Agriculture, Ecosystems and Environment, 240, 45-53.

Pocock, M., Evans, D. and Memmott, J. (2012). The robustness and restoration of a network of ecological networks. Science, 335, 973-7.

Prasad, R. P. and Snyder, W. E. (2004). Predator interference limits fly egg biological control by a guild of ground-active beetles. Biological Control, 31, 428-37.

Sanguankeo, P. P. and Leon, R. G. (2011). Weed management practices determine plant and arthropod diversity and seed predation in vineyards. Weed Research, 51, 404-12.

Saska, P., Van der Werf, W., de Vries, E. and Westerman, P. R. (2008). Spatial and temporal patterns of carabid activity-density in cereals do not explain levels of predation on weed seeds. Bulletin of Entomological Research, 98, 169-81. 
Shaffner, U. (2001). Host range testing of insects for biological weed control: How can tt be better interpreted? BioScience 51, 951-9.

Stewart, R. I. A., Dossena, M., Bohan, D. A., Jeppesen, E., Kordas, R. L., Ledger, M. E., Meerhoff, M., Moss, B., Mulder, C., Shurin, J. B., Suttle, B., Thompson, R., Trimmer, M. and Woodward, G. (2013). Mesocosm experiments as a tool for ecological climate-change research. In G. Woodward and E. J. O'Gorman (eds), Advances in Ecological Research, 48, 71-181.

Suckling, D. M. (2013). Benefits from biological control of weeds in New Zealand range from negligible to massive: a retrospective analysis. Biological Control, 66, 27-32.

Sunderland, K. (2002). Invertebrate Pest Control by Carabids. The Agroecology of Carabid Beetles. J. Holland. Andover, Intercept Publishers, pp. 165-214.

Symondson, W. O. C., Erickson, M. L. and Liddell, J. E. (1997). Species-specific detection of predation by Coleoptera on the milacid slug Tandonia budapestensis (Mollusca: Pulmonata). Biocontrol Science and Technology, 7, 457-465.

Tooley, J. and Brust, G. E. (2002). Weed seed predation by carabid beetles. In J. M. Holland (ed.), The Agroecology of Carabid Beetles, Intercept, Andover, pp. 215-29.

Traugott, M., Kamenova, S., Ruess, L., Seeber, J. and Plantegenest, M. (2013). Empirically characterising trophic networks: what emerging DNA-based methods, stable isotope and fatty acid analyses can offer. Advances in Ecological Research, 49, 177-224.

Trichard, A., Alignier, A., Biju-Duval, L. and Petit, S. (2013). The relative effects of local management and landscape context on weed seed predation and carabid functional groups. Basic and Applied Ecology, 14, 235-54.

Trichard, A., Ricci, B., Ducourtieux, C. and Petit, S. (2014). The spatio-temporal distribution of weed seed predation differs between conservation agriculture and conventional tillage. Agriculture, Ecosystems and Environment. 188, 40-7.

Vacher, C., Tamaddoni-Nezhad, A., Kamenova, S., Peyrard, N., Moalic, Y., Sabbadin, R., Schwaller, L., Chiquet, J., Alex Smith, M., Vallance, J., Fievet, V., Jakuschkin, B. and Bohan, D. A. (2016). Learning ecological networks from next-generation sequencing data. Advances in Ecological Research, 54, 1-39.

Wallinger, C., Sint, D., Baier, F., Schmid, C., Mayer, R. and Traugott, M. (2015). Detection of seed DNA in regurgitates of granivorous carabid beetles. Bulletin of Entomological Research, 105: 728-35.

Westerman, P. R., Wes, J. S., Kropff, M. J. and Van der Werf, W. (2003). Annual losses of weed seeds due to predation in organic cereal fields. Journal of Applied Ecology, 40, 824-36.

Westerman, P. R., Liebman, M., Menalled, F. D., Heggenstaller, A. H., Hartzler, R. G. and Dixon, P. M. (2005). Are many little hammers effective? Velvetleaf (Abutilon theophrasti) population dynamics in two- and four-year crop rotation systems. Weed Science, 53, 382-92.

Westerman, P. R., Dixon, P. M. and Liebman, M. (2009). Burial rates of surrogate seeds in arable fields. Weed Research, 49, 142-52. 
